OPEN ACCESS

Edited by:

Juana Camacho,

Instituto Colombiano de Antropología e Historia (ICANH), Colombia

Reviewed by:

Huan Yang

Huazhong Agricultural

University, China

Veronica Vazquez-Garcia,

Colegio de Postgraduados

(COLPOS), Mexico

Timothy Adams,

University of Bern, Switzerland

${ }^{*}$ Correspondence:

Stefania Errico

s.errico@hotmail.com

Specialty section

This article was submitted to

Social Movements, Institutions and

Governance,

a section of the journal

Frontiers in Sustainable Food Systems

Received: 02 April 2021

Accepted: 26 August 2021

Published: 24 September 2021

Citation:

Errico S (2021) Women's Right to

Land Between Collective and Individual Dimensions. Some Insights

From Sub-Saharan Africa.

Front. Sustain. Food Syst. 5:690321.

doi: 10.3389/fsufs.2021.690321

\section{Women's Right to Land Between Collective and Individual Dimensions. Some Insights From Sub-Saharan Africa}

\author{
Stefania Errico * \\ Centre for Agroecology, Water and Resilience (CAWR), Coventry University, Coventry, United Kingdom
}

Women represent a large part of the 2.5 billion people who depend on lands managed through customary, community-based tenure systems and are especially reliant on commons for their lives and livelihoods. They have very often limited and unsecured access to land and natural resources and tend to be excluded from decisions concerning them. Far from representing a homogenous group, they face varying challenges that are the result of multiple and intersecting forms of discrimination, whereby gender dynamics intersect with other characteristics, such as age, disability, ethnic origin, or socioeconomic status. Peasant and indigenous women, in many instances, face the compounded impact of the lack of recognition and violation of the collective rights of their communities, which is often the legacy of histories of colonization, conquest, dispossession and discrimination, and patriarchal norms, exacerbated by neoliberalism and the commodification of land and natural resources. The nexus between individual and collective rights is one of particular importance, but has received limited attention, including as regards the gendered effects of human rights violations of collective rights. In the present article, the nexus between collective and individual rights of peasant and indigenous women is illustrated by considering the experience surrounding the recognition and implementation of collective rights to land in Sub-Saharan Africa and the impact on women's right to land. The article argues that peasant and indigenous women's right to land is best protected through interventions aimed at guaranteeing both their collective and individual rights. There is a need to take into account and address simultaneously the barriers that indigenous and peasant women face with regard to their collective as well as their individual rights. These barriers include those ascribed to the discrimination and social, economic and political marginalization suffered by their peoples and communities, as well as those related to patriarchal power structures within and outside them. Addressing these barriers requires the respect, protection and fulfillment of both collective and individual human rights of women and a careful analysis of the interaction between these rights.

Keywords: women, peasants, indigenous peoples, land, human rights, Africa 


\section{INTRODUCTION}

Globally, women account for $<15$ per cent of all landowners, ranging from 5 per cent in the Middle East and North Africa to 18 per cent in Latin American and the Caribbean (FAO et al., 2020). They represent a large part of the 2.5 billion people who depend on lands managed through customary, community-based tenure systems and are especially reliant on commons for their lives and livelihoods. Despite playing a vital role in the food security of their families and communities, producing between 60 and 80 per cent of the food crops in developing countries, they have very often limited and unsecured access to land and natural resources and are excluded from decisions concerning them (United Nations, 2012a,b; Scalise, 2020). Unfavorable marital and inheritance laws, discriminatory social norms outside and within their communities, lack of participation in relevant decision-making institutions and processes, and lack of recognition of their productive role, among others, continue to pose challenges to women's access and control over land and natural resources in many cases (United Nations, 2012b; UN Committee on the Elimination of All Forms of Discrimination against Women, 2016; UN Working Group on Discrimination against Women and Girls, 2017). Women however do not constitute a homogenous group and the type and extent of the challenges they face is the result of multiple and intersecting forms of discrimination, whereby gender dynamics intersect with other characteristics, such as age, disability, ethnic origin, or socioeconomic status. Peasant and indigenous women ${ }^{1}$, in many instances, face the compounded impact of the lack of recognition and violation of the collective rights of their communities, which is often the legacy of histories of colonization, conquest, dispossession and discrimination, and patriarchal norms, exacerbated by neoliberalism and the commodification of land and natural resources. In this context, land grabbing stands out as a major challenge facing indigenous and peasant women and their communities which results in negative impacts on them at both collective and individual levels.

As expressed by the women of La Via Campesina, "the assumption that fair access to land can be achieved through market mechanisms and individual property is far from representing the views and aspirations of indigenous and peasant women" (LVC, 2013). Land is more than just a means of production. It is an integral part of the ways of life, culture, identity and spirituality of communities, and their members and thus is at the heart of their existence. Recognizing collective rights is a necessary complement to individual rights. For example, from the viewpoint of indigenous women, exercising their rights both as indigenous peoples and as women, depends on securing legal recognition of their collective ancestral territories: "Our territories are the basis of our identities, our cultures, our economies, and our traditions" (Foro Internacional de Mujeres Indígenas, 2006, p. 7). Protecting the collective relationship with

\footnotetext{
${ }^{1}$ For a definition of peasant, see article 1 of the UN Declaration on the Rights of Peasants and Other People Working in Rural Areas. For the identification criteria of indigenous peoples, see article 1 of the ILO Indigenous and Tribal Peoples Convention, 1989 (No. 169).
}

the territory is thus an indispensable step to ensuring the respect for distinct values, worldviews, cultures, and aspirations as well as the sustainability of livelihood strategies highly adapted to local contexts, which are often extremely fragile. As holders of collective identities and as women, indigenous and peasant women are both profoundly and distinctly affected by the lack of respect for and protection of these collective relationships (see sections Women's Collective Rights to Communal Land and The Interplay between Women's Collective and Individual Rights to Land $)^{2}$. At the same time, the protection of the latter does not necessarily translate into the protection of their individual rights or it may not be sufficient, due to the frequent prevail of patriarchal social norms both outside and within their communities. This article thus argues that peasant and indigenous women's right to land is best protected through interventions aimed at guaranteeing both their collective and individual rights.

The interplay of collective and individual rights features prominently in the international human rights instruments that specifically capture the human rights of indigenous peoples and peasants. The UN Declaration on the Rights of Indigenous Peoples (UNDRIP) and the UN Declaration on the Rights of Peasants and Other People Working in Rural Areas (UNDROP), for example, both recognize collective rights to land and natural resources grounded on customary land tenure systems as well as equal rights at the individual level ${ }^{3}$. Similarly, the Voluntary Guidelines on the Responsible Governance of Tenure of Land, Fisheries and Forests in the Context of National Food Security call upon States to recognize all legitimate tenure rights, including of indigenous peoples and other communities with customary tenure systems, and ensure equal rights between women and men.

The nexus between individual and collective rights is one of particular importance, but has received limited attention, including as regards the gendered effects of human rights violations of collective rights (see, for example, United Nations, 2015). Yet, both types of barriers faced by indigenous and peasant women, those concerning their individual and collective rights, need to be taken into account and addressed. These barriers include those ascribed to the discrimination and social, economic, and political marginalization suffered by their peoples and communities, as well as those related to the patriarchal power structures that can be found within and outside these communities. Addressing these barriers requires the respect, protection and fulfillment of both collective and individual human rights of women and a careful analysis of the interaction

\footnotetext{
${ }^{2}$ These groups are holders of distinct claims, so it is also important to bear in mind existing differences, although the challenges faced may look similar (see also Collins, 2019; Errico and Claeys, 2020).

${ }^{3}$ See, for example, UNDRIP, arts 21, 22, 26, 34, and 44; and UNDROP, arts $3,4,17$, and 21. In a similar vein, see ILO Indigenous and Tribal Peoples Convention, 1989 (No. 169), arts 3, 6, and 13-19. Please also note that the recognition of women's equal rights to land and property is grounded in core human rights instruments, including the Universal Declaration on Human Rights, the International Covenant on Economic, Social and Cultural Rights, International Covenant on Civil and Political Rights and the Convention on the Elimination of All Forms of Discrimination Against Women.
} 
between these rights. In the following sections, these aspects will be illustrated by considering the experience surrounding the recognition and implementation of collective or communal rights to land in sub-Saharan Africa and the impact on women's right to land. For the purpose of this article, the expression "right to land" is used to refer to the complex web of access, use, management and control rights on land and natural resources as captured, to a varying extent, by UNDROP and UNDRIP ${ }^{4}$.

UNDRIP and UNDROP provide the underlying framework for the analysis presented in this article. The complex web of access, use, management and control rights on land, and natural resources is thus understood to encompass a fundamental collective dimension. This dimension is grounded, on the one hand, on the right to self-determination of indigenous peoples, including their right to define their priorities for development and to maintain their distinct relationship with their territories, and, on the other, on the right to food sovereignty of peasants, including their right to participate in decision-making processes on policies, programmes, and projects that may affect them, as well as the right to maintain their ways of life (see further in Errico and Claeys, 2020). Accordingly, when examining the experience around the recognition and implementation of collective rights to land in sub-Saharan Africa, attention will be paid to women's individual rights to access, use, manage, and control land held by their communities under collective tenure systems, and their collective rights, especially as regards the facet of "control." Such collective "control" may extend, for example, to the ability to define and pursue a certain development path, maintain a distinct way of life with its culture, values and aspirations ${ }^{5}$ and, more broadly, counteract policies oriented at the marketization of the relationship with land. The interplay between individual and collective rights of indigenous and peasant women will also be examined by looking at the gendered impacts of the violation of the collective right to land of their peoples and communities, while noting that the information available on such interplay is overall scarce.

The article draws on a literature review that the author conducted in the framework of the research project "How to govern natural resources for food sovereignty?" of the Centre for Agroecology, Water and Resilience (CAWR), Coventry University, co-designed with Priscilla Claeys and Stefanie Lemke and aimed to analyse the potential and limitations of current and newly emerging legal frameworks for the protection of collective rights to land, seeds and natural resources. The literature review was directed at mapping legal and policy frameworks recognizing collective land rights and examining power relations and conflicts between different land users ${ }^{6}$. It covered sub-Saharan Africa, focusing in particular on East

\footnotetext{
${ }^{4}$ While these rights are intertwined with and interdependent on other civil, political, social, economic, and cultural human rights, which are all essential to women's agency, autonomy and identity and to the full enjoyment of their right to land, an analysis of all these aspects falls outside the scope of this article.

${ }^{5}$ In this respect, it is worth recalling that under international human rights law tradition, culture, and customs cannot be invoked to infringe upon human rights, including women's rights.

${ }^{6}$ For more details on the project, see: Lemke and Claeys (2020).
}

and West African countries ${ }^{7}$, and included information from studies and reports by international organizations, civil society organizations, and academic work concerning the experience of land reforms and more particularly the recognition and implementation of collective land tenure rights, in an overall context marked by land grabbing (see list of references) ${ }^{8}$. SubSaharan Africa was selected because the majority of the land area in Sub-Saharan Africa is held under customary forms of land tenure and most of the countries in the sub-continent have embarked on land law and policy reforms that, notwithstanding their specificities, show some commonalities, including the legal recognition of customary law as a source of land rights, the provision of measures to protect women's land rights and the decentralization of land administration ${ }^{9}$. Yet, as will be discussed below, implementation of these provisions remains challenging, resulting in both collective and individual threats to peasants and indigenous women's rights.

The literature review followed a broad definition of peasants, as included in UNDROP, and therefore encompassed also indigenous peoples. Most of the information available however did not pay a distinct attention to indigenous peoples, with the exceptions of few dedicated studies, and also scarcely engaged with the variety of repercussions, including spiritual and cultural, that women may suffer from the violations of the collective rights of their peoples.

The article is structured as follows. After providing an overview on communal land in Sub-Saharan Africa (sections Communal Land in Sub-Saharan Africa and The Implementation of Collective Rights to Land in Sub-Saharan Africa), the article will discuss women's individual and collective rights to communal land in the sub-continent (sections Women's Individual Rights to Communal Land and Women's Collective Rights to Communal Land). It will then move to illustrate the interplay between these rights, highlighting the nexus between the individual and collective dimensions of indigenous and peasant women's right to land (section The Interplay Between Women's Collective and Individual Rights to Land). Finally, some concluding remarks will be presented (section Conclusion).

\footnotetext{
${ }^{7}$ For the purpose of this article, Sub-Saharan Africa is understood to comprise the countries that lie South of the Sahara according to the list used in UN statistics (for the full list of countries, see http://unstats.un.org/unsd/methods/m49/m49. $\mathrm{htm})$. According to the same classification, Eastern Africa comprises the following countries: British Indian Ocean Territory; Burundi; Comoros; Djibouti; Eritrea; Ethiopia; French Southern Territories; Kenya; Madagascar; Malawi; Mauritius; Mayotte; Mozambique; Réunion; Rwanda; Seychelles; Somalia; South Sudan; Uganda; United Republic of Tanzania; Zambia; and Zimbabwe. Western Africa includes: Benin; Burkina Faso; Cabo Verde; Côte d'Ivoire; Gambia; Ghana; Guinea; Guinea-Bissau; Liberia; Mali; Mauritania; Niger; Nigeria; Saint Helena; Senegal; Sierra Leone; and Togo.

${ }^{8}$ The information examined included sub-regional assessments concerning SubSaharan Africa or Eastern and Western Africa as well as specific cases concerning Kenya, Tanzania, Uganda, Rwanda, Ethiopia, Ghana, Nigeria, Burkina Faso, and Mali. Some illustrations from Cameroon (Middle Africa) are also included, because they are particularly relevant to the discussion.

${ }^{9}$ For more details on the differences and commonalities within the sub-continent, see Alden Wily (2012).
} 


\section{COMMUNAL LAND IN SUB-SAHARAN AFRICA}

According to estimates, unregistered and untitled lands would account for 90 per cent of the total land area in Sub-Saharan Africa and would support about 60 per cent of all households (cross-country average), providing the basis for agricultural, pastoral, and other related livelihoods (Boone, 2018, ACET, 2016). Approximately 60 per cent of the national land area in Sub-Saharan Africa is reportedly held under customary forms of land tenure (RRI, 2015).

Although it may vary significantly across countries, customary tenure in Sub-Saharan Africa typically comprises defined individual or family rights to some type of land and land use along with common property resources. This is the reason why speaking of "communal tenure" has sometimes been contentious (Cousins, 2009). Under this system, however, rights are conferred to individuals or households on the basis of accepted group membership and a certain level of group control or supervision of land matters is maintained; thus a collective or communal dimension of the tenure is undeniable. In practice, customary tenure comprises complex bundles of individual, family, subgroups, and larger groups' rights and duties to a variety of resources (for ex: rights to farm, graze animals, hunt, gather wood, access water points, transverse, etc.), which confer on different actors' distinct access at different times (Cousins, 2009; Boone, 2018).

The distinctive features of these tenure regimes have been summarized as follows:

- "Land rights are embedded in a range of social relationships and units, including households and kinship networks and various levels of 'community'; the relevant social identities are often multiple, overlapping and therefore 'nested' or layered in character (e.g., individual rights within households, households within kinship networks, kinship networks within local communities, etc.).

- Land rights are inclusive rather than exclusive in character, being shared, and relative. They include both strong individual and family rights to residential and arable land and access to common property resources such as grazing, forests, and water.

- Rights are derived from accepted membership of a social unit, and can be acquired via birth, affiliation or allegiance to a group and its political authority, or transactions of various kinds (including gifts, loans, and purchases) [..]

- Access to land (through defined rights) is distinct from control of land (through systems of authority and administration).

- Control is concerned with guaranteeing access and enforcing rights, regulating the use of common property resources, overseeing mechanisms for redistributing access (e.g., transgenerationally), and resolving disputes over claims to land. It is often located within a hierarchy of nested systems of authority, with many functions located at local or lower levels.

- Social, political, and resource boundaries while often relatively stable are also flexible and negotiable, given the nested character of social identities, rights, and authority structures" (Cousins, 2009, p. 8).

The current situation concerning customary land tenure in the sub-continent is to be connected to historical processes dating back from colonial times. Overall, colonial powers claimed ownership or trusteeship of all land and followed two approaches to their governance (i.e., statist and new-customary), which continue to have an impact on present days' policies and legislation (Boone, 2015) ${ }^{10}$. In those cases where there was a direct interest in certain lands for urban development, mining, commercial plantations, or settlement of European farmers, colonial powers expropriated the lands from the local landholders and users and allocated them to European settlers or foreign companies, carrying out titling, and registration programmes. In these cases, the state acted as the direct allocator, enforcer and manager of rural land rights, creating also specific administrative and political institutions to govern these rights (so-called statist model) (Boone, 2015; ACET, 2016). This process was particularly evident in East and Southern Africa, for example in countries such as Kenya, Zimbabwe, South Africa, Namibia, and Mozambique.

In the vast majority of cases, however, colonial powers asserted their control over rural areas only indirectly through government-recognized tribal chiefs and elders. To this end, they made use of-and adjusted as needed-pre-existing customary tenure arrangements (Boone, 2015, 2018). Under this regime (so-called new-customary model), tribal territories as well as tribal authorities' power within these territories were recognized by the state. Tribal authorities' power encompassed, among others, the authority to: allocate unoccupied land; seize and reallocate land considered not in use; cede land to the central government; seize land needed for communal purposes; oblige widows and divorced women to turn over land to their inlaws; force younger men to submit to elders' decisions on land disposition and use; rule on land disputes within and among families; decide on inheritance cases; and enforce colonial landuse policies (such as forced terracing or destocking) (Boone, 2015). The powerful role attributed to traditional authorities in matters concerning land allocation has been regarded as one the exogenous characteristics introduced into pre-existing customary tenure arrangements by colonial authorities with the purpose of asserting control over rural areas (Krantz, 2015). This role helped establish a hierarchical relationship between collaborating African elites and their subjects, and, consequently, between those who had administrative powers over the land and those who worked the land or needed access to it (Boone, 2015).

\footnotetext{
${ }^{10}$ See also Kenfack Kenjio (2020) on the legacy of colonialism on land tenure systems in Sub-Saharan Africa. Despite the great diversity and specificities, due to localized historical, geographical, economic, social, political, and cultural factors, commonalities across the sub-continent have been observed (see also Cotula et al., 2004; Alden Wily, 2012). As noted by Nelson, three main juridical traditions form the basis for state land law across sub-Saharan Africa, and their geographical application is directly related to the systems imposed by the colonial powers, namely: English Common Law; Roman Dutch Law; and Civil Law Traditions (Nelson, 2004).
} 
Within the nested structures of extended families and households, senior males were given authority over the land farmed by women and youth along with claims to the labor of these members of the household (Cotula, 2007; Boone, 2015). This system also entailed the expansion of the territorial sphere of influence of certain customary authorities (the ones trusted by the colonial administration) to the expense of other (less trusted or distrusted) local leaders (Cotula, 2007; Boone, 2015). In some cases the demarcation of "tribal territories" resulted, in practice, in the assertion of the power of certain groups and their leaderships over others or imposed models of authority that were foreigner to the community concerned. These ("collective") aspects are all relevant when looking at the situation of women from an intersectional viewpoint. For example, the delimitation of territorial units and the emphasis on village structures, like in Mali, turns out to be challenging for nomadic pastoralists and undermines their participation in local governance (Cotula, 2007; Boone, 2015).

At independence, most governments confirmed the role that had been recognized to tribal chiefs, given the political potential inherent in this system of control. In general, existing land regimes were upheld by most independent governments, although debates over the need for the "modernization" of land tenure emerged throughout the 60s, 70s, and 80s (Cotula, 2007; Boone, 2018). In the 1990s, especially in the wave of the second-generation structural adjustment plans and under the influence of neoliberalism, new initiatives were undertaken to promote privatization of land holdings, titling, and registration. Nevertheless, States' interventions to convert customary rights in favor of individual titles issued by the state have had very limited results due to a variety of factors. These include: lack of financial resources and institutional capacity in government agencies; lack of perceived legitimacy of rules and institutions; rejection of individual titles by certain groups (for ex: pastoral and agropastoral communities in Kenya; or women whose names were not to be reported on the land titles); and the overall political dimension of customary tenure, i.e., the powers and entitlements attached to it (Cotula, 2007; Boone, 2015; Alden Wily, 2018).

Against this backdrop, policy recommendations ${ }^{11}$ for tenure reform have stressed the importance of the legal recognition of customary/collective land tenure as a response to the land-grabbing crisis, persistent poverty, food insecurity, social inequalities, and land degradation affecting peasants' and indigenous peoples' communities across the sub-continent. It has been argued that customary tenure systems would guarantee more inclusiveness, as rights to land and natural resources are conferred on community's members on the basis of their "membership," rather than being subject to exclusive ownership by particular individuals (on the implications of the concept of "membership" in particular for women, see further in the

\footnotetext{
${ }^{11}$ See also the "Framework and Guidelines for Land Policy in Africa" developed in 2009 by the African Union as a regional response to the land grabbing crisis affecting the continent, calling for the recognition and strengthening of customary land tenure and governance (AFSA, 2017). In 2010, the African Union also adopted the "Policy Framework for Pastoralism in Africa" with the aim of securing, protecting and improving the lives, livelihoods, and rights of pastoralist communities (African Union, 2010).
}

following sections) (Platteau, 2000; Freudenberger, 2011; Krantz, 2015). Customary tenure is also flexible in the sense that access to land and resources may be obtained through negotiation with community leaders or other members. Additionally, it may be cheaper for the Government to build its system of land administration on pre-existing institutions which may be perceived as more legitimate by local people.

On the other hand, customary/collective systems are not necessarily socially harmonious or egalitarian per se (Krantz, 2015). The relative endowments of different groups within a community, as defined on the basis of ethnicity, age, social status or gender, can differ significantly from each other (Cotula, 2007). Furthermore, the flexibility of customary tenure systems results, in practice, into a certain degree of ambiguity that can give rise to privileges and abuses as much as it can support the empowerment of the weakest members of the community (Peters, 2012). Moreover, commodification and individualization of land rights have occurred within customary systems, as a result of increasing land value and market integration. It has been observed that, as the value of land increases, the number of monetarized transactions on lands falling within customary tenure rises, pushing to greater individualization of land rights (Chauveau and Colin, 2007; Krantz, 2015; ACET, 2016). This occurs within a framework of "neo-liberal" land reforms which are designed "to craft a more market friendly customary tenure" and "create conditions that are more likely to result in the loss of land" (Chimhowu, 2019, p. 897 and p. 899), especially for the weakest (or rather most discriminated against) members of a community and the most marginalized and discriminated communities. Such an approach both disregards and contributes to the weakening of social, cultural, and spiritual significance of land (IIED, 2006). The increase in the commercialization of land relations leads to many land management decisions being taken at the household or even at the individual level, with repercussion on the actual functioning of customary institutions and specific impacts on women's right to land (Cotula, 2007). The emergence of individualism has furthermore affected communities' capacity to speak with one voice on land matters and defend their rights "collectively" (RRI, 2016).

In many countries, the role of the traditional authorities has been eroded and weakened by changes in the composition of the local population, external pressures on land as well as the competition with statutory authorities. The emergence of local economic powers has further challenged the role of traditional aristocracies (Cotula, 2007). In most countries, formal institutions for land administration have often been superimposed on traditional structures without clear definition of responsibilities and roles, with repercussions on their outreach and social legitimacy. The emergence of wealthy politically connected individuals in fact influence how land is managed at local level, thanks to the gaps created by land reforms which have failed to coordinate properly traditional institutions and statutory-based management authorities (Chimhowu, 2019). In other cases, traditional authorities have been able to keep their power, also thanks to strategic alliances with central government authorities and business elites, among others. In certain instances, the collegial bodies that used to oversee the 
work of the traditional authorities are however no longer in place, giving rise to problems of accountability (Cotula, 2007; see also NAMATI and Natural Justice, 2015).

Land reforms and the increased marketization of land have triggered a gradual change in the role of the traditional leadership away from their stewardship in trust for the community, with elites appropriating and disposing of the community land as their own (see also Akaateba, 2019; Kemigisha, 2021). This transformation has also repercussions on the application of customary norms recognizing and protecting women's rights. For example, a study concerning Ghana reports that accessing land through customary forms of allocation based on kinship or family relations is giving way to monetized transactions, which are creating uncertainty among customary right holders and are disintegrating customary forms of social insurance, thereby deepening inequalities and poverty (Akaateba, 2019). Similarly, in Nigeria a breakdown of the general sense of obligation which families and communities own toward their members, particularly women, has been registered (Nwapi, 2016; see also ILC and Mokoro, 2011 on processes of land commodification marginalizing women).

Research on customary tenure emphasizes the need for improving processes for community's participation in decisionmaking and introducing "checks and balances" on both customary authorities and government agencies that play a role in land negotiations with a view to ensuring that they act in the actual interest of the affected communities and their members (German et al., 2013, p. 14). Moreover, research points to the need for governance arrangements that are supportive of and take into account the diverse needs of heterogeneous users, with a particular attention to women, youth, indigenous peoples and the elders (Williams, 1998; Clarke, 2009; IFAD, 2018). In many cases women are not recognized as full members of the community and thus have no rights to vote and participate in land management decisions.

\section{THE IMPLEMENTATION OF COLLECTIVE RIGHTS TO LAND IN SUB-SAHARAN AFRICA}

The recognition and respect for customary collective land rights in Sub-Saharan Africa remains overall challenging and weak. Specific obstacles include increasing pressure on customary lands and land grabbing, which stems from a variety of factors ranging from the global demand for food, fuel and raw materials and large-scale infrastructure projects, to demographic growth, climate change policies, and natural conservation measures, among others. Additional obstacles are: biased approaches against certain forms of land-use; contradictory laws and policies; absence of mechanisms and capacity to ensure the actual implementation of relevant pieces of legislation recognizing customary rights; and the need to sustain and strengthen local institutions and support the process of communities' organization as legal entities and registration of lands when these are legally required (Veit, 2013; ACET, 2016; AFSA, 2017).
Across the continent, land concessions are granted in favor of investors in a context of uncertainty concerning customary land claims by communities and exploitation of current weaknesses of traditional communities' institutions. Even in countries where customary rights are formally recognized, the lack of registration make these rights vulnerable to appropriation in practice. In some cases, registration is left to the initiative of the interested community or individual who may face various obstacles in their efforts to register their rights, including the high costs of the procedure, lack of information, difficulties accessing land registries, and weak institutions (see, for example, KATOSI, undated). Social transformations led by the increasing individualization of rights, poses further challenges to the implementation of customary collective rights on the ground. Furthermore, growing land conflicts within communities, against local and national elites, and against public and private largescale investors have a bearing on the realization of customary land rights (KATOSI, undated). In most countries, no procedures for consultation or participation of concerned communities in decision-making concerning land-use or broader development planning are provided, leaving customary rights-holders with little, if any, capacity to oppose, influence or engage in decisions concerning large-scale investments affecting them, their livelihood and food security (African Commission on Human and Peoples' Rights, 2000; ILO/ACHPR, 2009; RRI, 2016).

According to estimates, 35-68 per cent of the global farmland acquisitions have been targeting sub-Saharan Africa (German et al., 2013). Between 2000 and 2016, African Governments concluded 422 large-scale land deals with investors, covering $\sim 10$ million hectares (AFSA, 2017). Whereas, in West Africa, the establishment of palm oil plantations was a dominant factor, in Eastern Africa infrastructure and energy projects triggered the majority of land acquisitions (RRI, 2016). The main cause of conflict in 63 per cent of cases is the forced displacement of persons, followed by environment degradation and the jeopardizing of local cultures (RRI, 2016). The process of actual acquisition of land by foreigners ranges from illegal acquisitions, based on secretive negotiations, to rapidly concluded contracts that, although legal, are affected by a strong asymmetry in power relations (Matondi et al., 2011).

In several cases, poor accountability, weak democratization and lack of transparency of local institutions contribute to abuses and corruption of elites that behave as "owners" of the communal lands, allocating or selling them for their own profit (Osabuohien, 2014; Booker et al., 2015). It is not uncommon that traditional leaders use their power, including political connections outside the community, to seize control of communal land for their own benefit or bend customary rules and practices to advance their political or economic interests (Rose, 2002; Peters, 2012; German et al., 2013). Often investors engage with leaders directly, and no consultation with the community is undertaken, creating opportunities for corruption and bribery (Booker et al., 2015; see also Nolte and Voget-Kleschin, 2014). Even in those countries that have adopted stronger legal frameworks on collective customary rights, conflict of interest or of mandate of government actors (investment promotion vs. monitoring 
and regulation), opportunities for personal enrichment by chiefs, modernization discourses coupled with discriminatory attitudes about customary land use practices, undermine in practice the legal protections (German et al., 2013).

Additionally, in many countries, the State disposes, in practice, of customary lands or the resources therein as if no communities' rights existed, especially in the case of lands deemed "unused" or "unproductively used"-as in the case of hunter-gatherers or pastoralists-, and in the absence of formal registration. Indigenous pastoral and hunter-gatherers' communities have thus increasingly been losing their lands to national parks and conservation areas, mining, logging, plantations, oil exploration, dam constructions, and expansion of areas for agricultural production (African Commission on Human and Peoples' Rights, 2000; ILO/ACHPR, 2009). In particular, livestock holdings have been reduced for pastoral communities and game resources, wild berries, roots and honey have become inadequate for hunter-gatherers, not to mention forced displacements leaving people with no livelihood alternative (African Commission on Human and Peoples' Rights, 2000; ILO/ACHPR, 2009). Certain communities, such as Batwa and Basongora in Uganda, and Samburu in Kenya have been rendered in fact landless.

The traditional approach of colonial and post-colonial administration has been to acknowledge communities' rights only to those lands that are used for housing and farming (RRI, 2011). This has typically left forests, rangelands, and marshlands without protection (RRI, 2011). The concept of lands in "productive use" or "visible use" has led to labeling certain areas as unused, "idle" or "vacant" even when, in practice, they are used by communities for their livelihood activities, especially in the case of nomadic and semi-nomadic peoples (see, for example, the cases reported in ILO/ACHPR, 2009). This also affects smallholder farmers, especially women, who use this land for growing crops or collecting wild food, firewood, building materials and other (see, for example, IIED, 2009 and see further below). Yet, some positive legislative developments have taken place in countries such as Ghana, Uganda, Tanzania, Southern Sudan, and Mali, which extend collective rights also to the communities' "commons," including forests, woodlands, and rangelands (Alden Wily, 2011, 2018; RRI, 2011; FAO, 2016).

\section{WOMEN'S INDIVIDUAL RIGHTS TO COMMUNAL LAND}

Women contribute significantly to food production in the subcontinent (Kimani, 2012). In Uganda, for example, 90 percent of all rural women work in agriculture. They are responsible for the production of about 80 percent of food crops and more than 50 per cent of cash crops ${ }^{12}$. In Ethiopia, women represent 45 percent of the agricultural labor force ${ }^{13}$. In Mali, 43 per cent of women

\footnotetext{
${ }^{12}$ See http://www.fao.org/gender-landrights-database/country-profiles/countrieslist/general-introduction/en/?country_iso3=UGA.

${ }^{13}$ http://www.fao.org/gender-landrights-database/country-profiles/countries-list/ general-introduction/en/?country_iso3=ETH.
}

are engaged in agriculture ${ }^{14}$. In Burkina Faso, about 95 per cent of women in rural areas practice subsistence agriculture ${ }^{15}$.

Albeit in constant evolution, there is a division of roles between men and women within farmers', pastoralists' and other rural communities. For example, within farmers' communities, women tend to be more involved in activities such as planting, weeding, watering, harvesting, and transportation of farm produce (Duncan and Brants, 2004). Men, in turn, are responsible for the initial clearing of the land, the tilling of soils and the marketing of larger amounts of farm produce (Duncan and Brants, 2004). Also, women are more involved in food crop production, while men engage rather in cash crop production (Duncan and Brants, 2004). In pastoralists' communities ${ }^{16}$, men look after the livestock and are in charge of conducting dispute resolutions and negotiations with neighboring communities and disputing parties, whereas women are mainly tasked with food supply for the family and household affairs (AFSA, 2018). For example, among the Maasai, herding is the main responsibility of men and boys. Women and girls, instead, are engaged in farming and various other activities such as petty trading and "merryground," i.e., women establish mutual support groups through which they pool funds to support, for example, the purchases of key household items (Charapa Consult, 2012). In the same vein, among hunter-gatherers communities, like the Batwa, men are in charge of hunting while women gather food products (Charapa Consult, 2012). Concerning fishing communities, according to research on fishing communities in Uganda, traditionally, women have been engaged in smoking or sun drying fish, i.e., all activities that are undertaken on the land. However, as communities lose access to these lands because of appropriation by third parties, women are forced to quit fishing-related activities and face great difficulties in finding other means of survival (KATOSI, undated).

Within customary collective land tenure systems, women usually gain access to land and natural resources through their relationship with a male relative (husband or male member of their native lineage, normally the father) (FAO, 2011; Scalise, 2012; Krantz, 2015; Andersson Djurfeldt, 2020) ${ }^{17}$. As a result, they are rarely compensated for their losses in case of land dispossession. Moreover, they lose access to land if the relationship no longer exist (in case, for instance of divorce or the death of the husband). Under certain customary laws, widow women may be forced to wife inheritance and ritual cleansing practices to keep access to land. They are "married" to a male relative of the deceased husband following a "cleansing" ritual, involving coerced sex with a social outcast, supposedly to free the woman from the deceased husband ${ }^{18}$.

\footnotetext{
${ }^{14} \mathrm{http} / /$ www.fao.org/gender-landrights- database/country-profiles/countries-list/ general-introduction/en/?country_iso3=MLI.

${ }^{15} \mathrm{http} / / / \mathrm{www}$. fao.org/gender-landrights-database/country-profiles/countries-list/ general-introduction/en/?country_iso3=BFA.

${ }^{16}$ In the same vein, among hunter-gatherers communities, like the Batwa, men are in charge of hunting while women gather food products (Charapa Consult, 2012).

${ }^{17}$ Reference is made here to patrilineal descent systems, which are the predominant system in Sub-Saharan Africa (Krantz, 2015), although exceptions are found, especially in Central and Southern Africa (Andersson Djurfeldt, 2020).

${ }^{18}$ See, for example, Kenya country profile at www.fao.org/gender-landrightsdatabase.org.
} 
Mostly, women contribute to men's livelihood activities, providing their labor. They may cultivate parts of the land that is allocated to their husband or their husband's clans. They are recognized (secondary) ${ }^{19}$ rights to a small garden, the outputs and incomes of which they may exercise control over (WoMin (African Women Unite against Destructive Resource Extraction), undated). They also access and use common resources within the collective tenure system, such as forests, woodlots, communal food gardens and shared water resources, in order to supply water, food and wood to their families (WoMin (African Women Unite against Destructive Resource Extraction), undated). In Burkina Faso, for example, land is distributed to men who are however expected to allocate a portion of this land to their wives. The latter will have control over the products of this land but they also have to help cultivate their husbands' lands. Although customs may vary across groups, women are freed from the obligation to cultivate their husbands' land at the age of 45 years, once their children are deemed to be old enough to contribute to the cultivation of the land. If divorced, a woman can marry again to gain access to land or she can borrow land from other community's members ${ }^{20}$. Overall, women's situation with regard to access to land and natural resources is therefore determined, on the one hand, in relation with the community (and its membership), and, on the other hand, in relation to the members of the household (LANDESA and Resource Equity, 2016).

In most customary collective tenure systems, it is men who own land and inherit it (FAO, 2011). The notion of community membership has also a bearing on women's access to land and natural resources. Not only is this relevant in those cases where women are married into the community and, as a consequence, in case of divorce or death of the husband, the lands they use may be reclaimed by the husband's family. But, more broadly, membership in a clan determines men's rights to land and resources, not women's, as if they were not regarded as full community members (Scalise, 2012, 2020; Krantz, 2015).

Before colonial times, ownership and access to land were similarly vested in lineages, clans and families, with male leaders exercising day-to-day control. Members of a particular lineage or clan would seek rights to use land from these community or family leaders. Women rarely had full rights to land and were mostly regarded as secondary claimants, through male relatives. With the exception of a few matrilineal communities, lands rights were typically inherited only by men. Yet, women were ensured continued access to land also after separation, divorce or widowhood and could appeal to traditional means of arbitration if their access to land and resources was contested (Interview with Cousins as reported in Kimani, 2012).

At present, local chiefs who decide on land allocation have in most cases a particular cultural understanding of the role of

\footnotetext{
${ }^{19}$ By secondary rights reference is made to those entitlements that are not permanent in nature and depend on the primary right and his/her holder for their existence. This is what happens, for example, in the case of women's rights within customary tenure systems, whereby women are provided access land and natural resources through a male relative.

${ }^{20}$ See country profile at www.fao.org/gender-landrights-database.org.
}

women (not recognizing nor valuing their productive role) and, as custodians of community's culture, tend to perpetuate it in their decision on land allocation (Kimani, 2012; Akinola, 2018). It is also men who are in charge of local dispute-resolution systems, whereas court systems are both too expensive and "intimidating" for women to access them (Kimani, 2012). Furthermore, as has previously been recalled, the increasing commodification and individualization of land rights occurring within customary systems has triggered intra-household competition between men and women-and between generations-over productive resources, with family property being in fact "privatized" by senior male members (IIED, 2006). This is coupled with the continuing lack of voice of women in land governance-and decisions being thus taken under commercial pressures on land without women's participation-, and is further aggravated by the fact that local accountability mechanisms are either not available or they cannot be activated easily by women (IIED undated ${ }^{21}$ ).

Downward accountability of traditional authorities toward the members of the community, especially women, remains in some cases a major issue, with the latter having limited ability to question the authority of local leaders due to customs, intimidation, coercion by outside actors or legal illiteracy (German et al., 2013). At the same time, community members, particularly women, also face barriers to access formal dispute resolution mechanisms, including social stigma associated with their use (Andersson Djurfeldt, 2020; Doss and MeinzenDick, 2020). Thus, women see their control over land and natural resources severely restrained in many cases because they lack participation in the land administration institutions and cannot access accountability mechanisms, while decisions are increasingly taken at the household level where their voice is similarly limited (see previous section).

Some states have attempted to strengthen women's tenure rights either within marriage or as individuals or both. In Uganda, for example, spousal consent to land transactions is required under the Land Law and customary law is recognized to the extent that it is not discriminatory against women, children and persons with disabilities. In some countries, like Ethiopia, measures have been adopted to register lands in women's name (IIED, 2006; FAO, 2011). In 2003, Ethiopia introduced land title certifications which would be issued jointly in the name of spouses. Ethiopia's land programme also provides for the issuance of land certificates bearing women's photo on them in order to avoid manipulations and ensuring security of tenure for women (FAO, 2011; ACET, 2016). The requirement for women's representation in land administration committees at local level (they should comprise at least one female member) has contributed in practice to the issuance of land certificates that reflect women's rights (FAO, 2011). In Rwanda, following the 1994 genocide, new legislation was passed recognizing women' inheritance rights on an equal footing with men so as to allow widows and female orphans to secure land (Kimani, 2012). The

\footnotetext{
${ }^{21}$ Gender, Land and Accountability in the Context of Agricultural and Other Natural Resource Investments. Available online at: https://www.iied.org/genderland-accountability-context-agricultural-other-natural-resource-investments (accessed March 13, 2021).
} 
National Land Policy of 2004 and the Organic Land Law of 2005 , besides recognizing equal rights to daughters and sons to inherit property belonging to their parents, also require for both women and men to provide consent in the case of sale, mortgage, or exchange of matrimonial property by any of the partners (ACET, 2016). In a similar vein, in Ghana a "head of family accountability" provision was adopted to ensure that family property cannot be sold without others being informed, giving consent or benefiting from the proceeds (Kimani, 2012).

Nevertheless, these efforts still face the challenges of strong local practices favoring men (FAO, 2011). In Uganda, for example, the National Land Policy (NPL) acknowledges the existence of "land grabbing at family level" (National Land Policy of Uganda, 2013, para. 63) due to the predominance of discriminatory customs that override, in practice, legal provisions. It lays down that the Government shall, by legislation, protect the right to inheritance and ownership of land of women and ensure that both men and women enjoy equal rights to land before marriage, in marriage, after marriage and at succession without discrimination. In this connection, it identifies among the strategies to be pursued: reviewing customary rules to avoid violation and abuse of family land held in trust for the family; ensuring that the head of family is held to account on his fiduciary duties over family land held in trust; restoring the power of traditional leaders in matters of land administration on condition that the rights of "vulnerable groups" are taken into account; amending relevant legislation to provide for the right to succession and inheritance of family land by women and children; and ensuring that women are fully integrated in all decision-making structures and processes on access to and use of land (National Land Policy of Uganda, 2013).

Case studies point out that in order to promote sustainable social changes that are needed for women to have secure and equitable land rights, it is essential to build on existing customary practices and social norms that positively affect women. In this regard, it is crucial to collect information about how women and men use and control land, how community decisions are made and what role women play in community governance, how wealth is distributed within the household through inheritance and dowry or bride price, what customs exist for caring for the elderly or widowed, among others (LANDESA and Resource Equity, 2016, p. 12).

Various initiatives have been taken at country level to ensure women's participation in internal community governance. For example, the case of Tanzania offers interesting insights. Local governance in Tanzania is entrusted in village assemblies together with village councils that are accountable to the village assembly for land management decisions (IIED, 2006). Minimum ratios of women's representation in these bodies are established by law but, in practice, women rarely participate effectively in them and, when represented, their opinions are rarely taken into account in land administration decisions. Research on Tanzania's experience has identified some main causes for women's limited participation which include women's high levels of illiteracy, the timing of village assembly and village council meetings, the burden of domestic chores and the impact of local customary practices which in fact restrict women's ability to speak out (IIED, 2006). Furthermore, legislative provisions recognizing women's rights are not enforced in practice by the institutions charged with managing and administering land (IIED, 2006). On the other hand, an important entry point to strengthen women's rights within customary tenure has been found in the development of village by-laws regulating internal governance, which falls within the mandate of village councils. Thus, the Tanzania Women Lawyers Association (TAWLA), in collaboration with the World Resources Institute (WRI) and Lawyers' Environmental Action Team (LEAT), has developed model by-laws to improve women's participation in decisionmaking at local level on village land management. These model by-laws were developed through a bottom-up, participatory process and enshrine some key principles, such as: (i) Gender quotas in leadership of village-level governance bodies (village council, village committees, village land council, etc.); (ii) Mento-women rotation of leadership (village chair person, village land council, chairs in different committees); (iii) $50 \%$ of men and $50 \%$ of women in councils and committees (equal representation-promote women's representation, especially in village councils); (iv) Specific quorums for village assembly meetings that includes equal representation of men and women; and (v) Meeting quorums to be equally comprised of men and women (village assembly, village committee, village council) (Kisambu, 2016).

Likewise, research on Kenya has emphasized the need to ensure that legislation on collective land tenure incorporates affirmative action measures to ensure women's representation in all levels of community land governance, besides measures designed to address underlying constraints to women's involvement in governance (Chan and Mbogoh, 2016; see also IWGIA, 2020). In Uganda, Communal Land Associations have been promoted by the Government with a view to securing community land tenure and, at the same time, to sensitizing on gender issues and including women inland governance. It has been reported that this initiative has triggered profound change in the attitudes toward women's land rights, among both women and men. Moreover, gender quotas in communal land management committees have helped increase women's voice and narrowing the gap on land rights at community and household levels (International Land Coalition, 2020 reporting research by Lakidi Achan).

\section{WOMEN'S COLLECTIVE RIGHTS TO COMMUNAL LAND}

As has been illustrated in the previous section, despite their role within their communities and households, in most customary systems women are not recognized independent rights to land and natural resources and they rarely participate in decisionmaking concerning the use of these resources. Women have organized to fight for their rights to inherit, purchase, and own land in their own name, embracing a human-rights based discourse, exactly at a time when an increasing number of States in the sub-continent is recognizing customary land tenure in their legal and policy frameworks (Tripp, 2001). Whereas, 
the recognition of collective rights has been deemed to be particularly important for women, the formal registration of these rights brings about the risk of further marginalization for women, unless specific attention is paid to their interests in collective lands and secondary rights are sufficiently safeguarded (IIED, 2006; LANDESA and Resource Equity, 2016; BourkeMartignoni, 2019; Chimhowu, 2019). At the same time, women's right to land is affected also by dynamics operating at collective level with regard to the recognition and implementation of the collective right to land of their communities and the violations of this right. Unsurprisingly, women have also mobilized to defend the collective rights of their communities (see, for example, La Via Campesina, 2015; United Nations, 2015). For instance, women have played a key role in organizations such as the Uganda Land Alliance, the National Land Forum in Tanzania, the Zambia National Land Alliance, National Land Committee in South Africa, Kenya Land Alliance, Rwanda Land Alliance, and the Namibian NGO Federation (NANGOF), which have fought for the rights of women, pastoralists, the landless, and other marginalized groups (Tripp, 2001).

Women's rights are part of the complex web of rights captured under collective land tenure systems. The lack of recognition of their community's collective rights has therefore implications for them. Since land has a special significance that goes beyond economic considerations alone, those implications are broad and deep, as has been recalled in the introduction. The recognition of collective land rights has indeed a bearing on a wide array of collective and individual rights, which extends to the rights to life and development, to enjoy one's culture; to health, including sexual and reproductive health; and adequate standard of living, including adequate housing, among many others, as well as the right to self-determination of indigenous peoples and the right to food-sovereignty. The impacts of the violation of collective land rights are thus profound as well as gendered.

Indigenous women, for example, have highlighted that the systematic violation of their collective rights as indigenous peoples is the single greatest risk factor for gender-based violence, including violence perpetrated within their communities (Foro Internacional de Mujeres Indígenas, 2006). Such systematic violation of their collective rights encompasses land dispossession. They have moreover explained that indigenous traditions and indigenous women themselves identify women with the Earth, and therefore perceive degradation of the Earth as a form of violence against women. "This conviction is more than a metaphorical allusion to Mother Earth. It is rooted in Indigenous cultural and economic practices in which women both embody and protect the health and well-being of the ecosystems in which they live" (Foro Internacional de Mujeres Indígenas, 2006, p. 16). In this sense, they have emphasized that "corporate encroachment threatens the economic survival of Indigenous communities, the ecological health of their territories, and the traditional roles of Indigenous women within their communities. Each of these effects entails forms of violence against Indigenous women," including violence in its spiritual dimensions (Foro Internacional de Mujeres Indígenas, 2006). As has been noted in the previous sections, when communities lose their lands, women rarely receive any compensation for the loss suffered in case of eviction from their community's land, because of the "secondary" nature of their rights. However, the lack of compensation has also been attributed to the fact that their losses are difficult to estimate in monetary terms (Doss and Meinzen-Dick, 2020).

Indigenous and peasant women are also disproportionately affected by land dispossessions suffered by their communities because of their multiple roles within their communities and household (see also Behrman et al., 2012; Scalise, 2012; Ndi, 2017). For example, they may have to walk longer distances to provide for water and firewood, which leaves them less time for productive activities. Their traditional knowledge about seeds or medicinal plants may be gradually lost, weakening their position within their communities. Finding an alternative occupation may also be much harder for them than for men, due to varying factors reflecting overall gender inequalities in society, such as lower education, language barriers, family-care responsibilities and multiple forms of discrimination, which may increase their dependence on men and may expose women and girls to heightened risks of sexual exploitation and forced and early marriages. In the context of a field study undertaken in Cameroon, some indigenous women also reported that land dispossessions deprived them of the medicinal plants that their communities traditionally use to attend to pregnant women and children (ILO, 2021). This aspect is critical for many rural communities in other countries in Sub-Saharan Africa that are underserved, often due to their geographical remoteness.

Furthermore, displacement plans in many cases are not developed nor implemented taking into consideration their specific needs, including those related to their livelihoods. Thus, they may not contemplate the provision of vegetable gardens near the new housing, or water points in its vicinity or ways of ensuring fuel, wood or others needed for cooking, among others. This is often the result of the lack of collective consultation with the community affected and, in the cases-rare-where such consultations are undertaken, it is often the consequence of women's lack of voice within their communities, as has previously been illustrated (see also Doss and Meinzen-Dick, 2020). Women's lack or limited voice within their communities is sometimes coupled with an absence of attention and special measures toward them by the external actors involved (see further below).

More generally, indigenous and peasant women and their communities rarely participate in decision-making concerning them (see also Levien, 2017; Doss and Meinzen-Dick, 2020). As has previously recalled, this includes decisions about development and other projects affecting their lands but also public policies that may thus fail to take into account and support their livelihood strategies and collective and individual needs and may undermine their ways of living. For example, women's right to land has been restrained as a result of the introduction of policies oriented at export production, which resulted in men pressuring on plots of land traditionally used by women as vegetable gardens (Andersson Djurfeldt, 2020). Such policies have also accentuated the process of commodification of land that has triggered the breaking down of kinship-based mechanisms of support and the appropriation of land to the 
detriment of women that have been illustrated in the previous sections. Moreover, the interplay of collective and individual lack of participation also affects women's opportunity to receive extension training and advisory services on product development and marketing (see ILC and Mokoro, 2011; Behrman et al., 2012). Moreover, as women have distinct uses of the common resources held under collective tenure systems, their lack of voice in the decision-making processes concerning them, whether within their community or with external actors, especially affects them and has repercussions on their communities as a whole (see also below).

\section{THE INTERPLAY BETWEEN WOMEN'S COLLECTIVE AND INDIVIDUAL RIGHTS TO LAND}

The formalization of tenure rights, when entailing the individualization and subdivision of communally held grounds, adversely impacts women's rights and livelihoods not only because women's right to land may be not recognized, as land is appropriated by elites or male members of the household (see section The Implementation of Collective Rights to Land in Sub-Saharan Africa), but also because collective dynamics are affected, producing negative effects on women. For example, a study on the effects of privatization of land in the River Njoro Watershed, in Kenya, on the two communities living in the watershed, namely the indigenous pastoralist Maasai of Narok and the indigenous hunting and gathering Ogiek people of the Mau forest, revealed that women's user rights were not recognized and the traditional exchanges between communities were replaced by individual transactions that bypassed women. In the past, the elders of the two communities used to negotiate the conditions under which the Maasai were allowed to move their cattle on the Ogiek hunting grounds, in exchange for a payment in kind of, for example, milk, meat and skin, that was then used by the community's women (Andersson Djurfeldt, 2020 referring to a study by Kyalo and Chiuri). The rising value of land in combination with the formalization of land rights has now led to a shift from a collective negotiation to a negotiation with individual male landholders only, with payments being made in cash. Maasai women have similarly lost access to precious resources on which they relied because of the subdivision and privatization of ranch lands. For example, when livestock is moved to pasture in the watershed, land is rented to wheat farmers to gain an income. In order to make land suitable for wheat cultivation, and thus rentable, all vegetation is cleared, depriving women of access to firewood in the proximity of their home. Moreover, since all livestock is moved to enable renting the land out to farmers, women have also lost their user rights to lactating cows (Andersson Djurfeldt, 2020).

In addition, whereas women usually use common resources within the collective tenure system, such as forests, woodlots and communal food gardens, those resources are often regarded by the State as "vacant" lands (see sections Communal Land in Sub-Saharan Africa) and may therefore be more frequently targeted for acquisition ${ }^{22}$. In some cases, the "targeting" of the lands used by women also depends on the fact that women tend to cultivate annual crops while men engage in the cultivation of pluriannual crops. In Cameroon, it has been observed that the nature of the crops offers men a greater security vis-à-vis the threat of evictions, because the lands used by women are considered "vacant" between planting seasons (Ndi, 2017). For this reason, some women have reportedly begun to engage in growing cash crops similar to those cultivated by men, thereby reducing food crops with repercussions on local food security, among others (Ndi, 2017). Moreover, as has been recalled above, women may be more affected by loss of marginal lands where plants with spiritual or medicinal functions are grown, because of their specific roles within their communities and the multi-fold significance of land which has been described above (see also Behrman et al., 2012). Thus, "there is a clear imperative to protect common lands not just as resistance to the incursion of financialization and privatization, but as a means to not undermine gender-differentiated land use that benefits communities as a whole" (Collins, 2019, p. 465).

Notwithstanding all the above, the recognition of collective rights is not sufficient to guarantee women's land rights and other related rights, because of patriarchal social norms that may prevail outside and within their communities. The formalization of collective rights may bring about a considerable risk for women to lose their individual rights to land, especially if no special attention is paid to those rights and no special measures are adopted to strengthen their control over the management of land (see previous sections). As has previously been recalled, various measures have been adopted at national level to strengthen women's tenure rights either within marriage or as individuals or both, and to ensure their participation in decision-making processes, including establishing quotas in land governance bodies and taking some steps to address underlying constraints to women's involvement in governance. However, even in those countries where the legislation provides for gender equality, including with reference to land rights, women's rights are in practice affected by poor implementation at local level, because traditional customs tend to prevail in the day-to-day practice, including when government officials are involved (see also Collins, 2019; Andersson Djurfeldt, 2020; Doss and Meinzen-Dick, 2020; Mengesha et al., 2021; see previous sections).

A more nuanced understanding of the gender consequences of recent land reform efforts is needed, as trying to remove a community-based land allocation practice that appears to be discriminatory, may in fact disrupt the basis for kinshipbased practices of solidarity and cooperation on which the community, including its women members, depends. Thus, for example, strengthening wives' rights may come at the expenses of the rights of the female siblings of the husbands (Collins and

\footnotetext{
${ }^{22}$ As emerged from a study in Cameroon with reference to forested lands, the loss of these lands is perceived by men too as a great loss to their community because of the socio-cultural value of these lands (Ndi, 2017).
} 
Mitchell, 2018; Peters, 2019; see also Andersson Djurfeldt, 2020). Research on Kenya pointed out that the focus of customary law is the well-being of the community rather than the claim of the individual, thus decisions are typically "compromises" rather than clear decisions for one party against the other. From this perspective, "communal norms can therefore be understood as a way of maintaining male power but also social harmony in concrete, village level contexts" (Andersson Djurfeldt, 2020, p. 6). At the same time, women can increase their ability to benefit from land resources within their community setting, thanks to the relational mechanisms applicable in that setting (Po and Hickey, 2018). Some authors have consequently maintained that existing customary institutions should be built upon wherever useful to support women (and other community members who may vulnerable to discrimination), but alternative strategies should also be pursued where such institutions are weak or corrupted and where discriminatory outcomes prevail (Collins and Mitchell, 2018; Massay, 2020)23.

In sum, it is crucial to reconcile both collective and individual rights of women and deepen current knowledge of the interplay between them from the perspective of women, based on an understanding of land that can capture its multi-fold significance for indigenous and peasant women and their communities as well as the distinctions existing between these groups (see next section; see also Collins, 2019).

\section{CONCLUSION}

The nexus between individual and collective rights is one of particular importance, but has received limited attention, including as regards the gendered effects of human rights violations of collective rights. Land is more than just a means of production. It is an integral part of the ways of life, culture, identity and spirituality of communities and their members. In this vein, recognizing collective rights is a necessary complement to individual rights. Peasant and indigenous women's right to land are best protected through interventions aimed at guaranteeing both their collective and individual rights. Experience surrounding the implementation of collective land rights in Sub-Saharan Africa points to the risks for women's rights inherent in the lack of recognition and protection of collective land rights. It also highlights the risks that stem from a recognition of collective land tenure which neglects to uphold women's individual rights to access and control land and natural resources on an equal footing with the male members of their communities and peoples. In fact, given the dependent or secondary nature of women's entitlements to land and natural resources within collective tenure systems, women face a great risk of losing out in any process of individualization of land rights, but this holds also true in case of recognition of collective/customary land tenure that only takes into account primary rights and is not sufficiently

\footnotetext{
${ }^{23}$ See also Daley and Englert (2010) reporting findings from research concerning Northern Uganda, Malawi, and Ethiopia supporting this approach and "pragmatic" solutions.
}

informed by a gendered analysis of access to land and resources within the community.

Measures taken in the areas of family and inheritance laws, for example, are in themselves insufficient to address the challenges faced by women, if these measures are adopted in isolation from other interventions that should tackle collective threats, including land grabbing and speculation. The opposite also holds true, because the protection of collective rights does not necessarily translate into the protection of women's individual rights or it may not be sufficient, due to the frequent prevail of patriarchal social norms both outside and within their communities. In other words, both types of barriers faced by indigenous and peasant women, those challenging the realization of their individual rights as well as those related to their collective rights need to be taken into account and addressed. Addressing these barriers requires the respect, protection and fulfillment of both collective and individual human rights of women and a careful analysis of the interaction between these rights, in consultation with the communities concerned. UNDRIP and UNDROP, which both capture the individual and collective rights of women and the fundamental interplay existing between them, provide fundamental guidance in this regard.

Solutions should be found at community level, including for the sake of their effectiveness and sustainability, with full respect for the collective rights of the communities, including indigenous peoples' right to self-determination, as well as the individual rights of their members. FIMI has observed, for example, that certain indigenous cultural values, including gender complementarity, have been eroded or eradicated because of colonization and religious conversion. "Yet, a process of remembering and reclaiming this traditionwhat some Indigenous anti-violence activists have termed 'retraditionalization'-can serve to reactivate it" (Foro Internacional de Mujeres Indígenas, 2006, p. 23). The direct engagement and consultation with women and girls remain essential in this regard (see, for example, United Nations, 2015). It has been demonstrated in a number of countries that "a nuanced, contextual understanding of customary norms may enable them to be successfully used to promote gender equality and food security" (Bourke-Martignoni, 2019, p.13).

Customary tenure has never been static and has, indeed, evolved significantly over the years, including in response to external pressures and influences. In the context of current debates on the recognition and protection of customary/collective rights to land and resources in SubSaharan Africa, there appears to be a need to bring clarity and "document" customary practices, particularly from the viewpoint of women. It is worth recalling that the notion of customary rights has been wielded for diverse purposes by multiple actors who have a stake in the political prerogatives, protections, and promises it can provide (Boone, 2015). In some cases, local actors advocating for community-based solutions for land governance have requested that "changes" be brought to customary institutions, voicing concerns about abuses by elites, lack of inclusiveness of traditional governance, discriminatory norms, and weak position of certain community's members. More research is also needed on gendered use of common 
resources within collective tenure and the norms regulating their allocation and use.

\section{DATA AVAILABILITY STATEMENT}

The original contributions presented in the study are included in the article/supplementary material, further inquiries can be directed to the corresponding author/s.

\section{AUTHOR CONTRIBUTIONS}

This research was carried out by SE.

\section{REFERENCES}

ACET (2016). Securing Land Tenure and Easing Access to Land. Available online at: http://www.acetforafrica.org (accessed March 13, 2021).

African Commission on Human and Peoples' Rights (2000). Report of the African Commission's Working Group on Indigenous Populations/Communities, Adopted by the ACHPR at its 28th Ordinary Session, DOC/OS (XXXIV)/345.

African Union, African Development Bank and Economic Commission for Africa (2010). Framework and Guidelines on Land Policy in Africa (Addis Ababa).

AFSA (2017). Policy Trends and Emerging Opportunities for Strengthening Community Land Rights in Africa (Kampala).

AFSA (2018). Recommonisation Secures Pastoralist Production, Livelihoods and Ecosystem Integrity in Olgos, Kenya. Available online at: http://www.afsafrica. org/case-studies/ (accessed March 13, 2021).

Akaateba, M. A. (2019). The politics of customary land rights transformation in peri-urban Ghana: powers of exclusion in the era of land commodification. Land Use Policy 88:104197. doi: 10.1016/j.landusepol.2019.104197

Akinola, A. O. (2018). Women, culture and Africa's land reform agenda. Front. Psychol. 9:2234. doi: 10.3389/fpsyg.2018.02234

Alden Wily, L. (2011). The law is to blame: the vulnerable status of common property rights in Sub-Saharan Africa. Dev. Change 42, 733-757. doi: 10.1111/j.1467-7660.2011.01712.x

Alden Wily, L. (2012). Customary Land Tenure in the Modern World Rights to Resources in Crisis. Washington, DC: Reviewing the Fate of Customary Tenure in Africa, RRI.

Alden Wily, L. (2018). Collective land ownership in the $21^{\text {st }}$ century: overview of global trends. Land 7:68. doi: 10.3390/land7020068

Andersson Djurfeldt, A. (2020). Gendered land rights, legal reform and social norms in the context of land fragmentation - a review of the literature for Kenya, Rwanda and Uganda. Land Use Policy 90:104305. doi: 10.1016/j.landusepol.2019.104305

Behrman, J., Meinzen-Dick, R., and Quisumbing, A. (2012). The gender implications of large-scale land deals. J. Peasant Stud. 39, 49-79. doi: 10.1080/03066150.2011.652621

Booker, S., Knight, R., and Brinkhurst, M. (2015). Protecting Community Lands \& Resources in Africa: Grassroots Advocates' Strategies \& Lessons. Natural Justice and Namati. Available online at: https://namati.org/wp-content/uploads/2016/ 01/Protecting-Community-Lands-and-Resources-in-Africa-Namati-andNatural-Justice-LR.pdf

Boone, C. (2015). Land tenure regimes and state structure in rural Africa: implications for the forms of resistance to large-scale land acquisitions by outsiders. J. Contemp. Afr. Stud. 33, 171-190. doi: 10.1080/02589001.2015.1065576

Boone, C. (2018). Legal empowerment of the poor through property rights reform: tensions and trade-offs of land registration and titling in Sub-Saharan Africa. J. Dev. Stud. 55, 384-400. doi: 10.1080/00220388.2018.1451633

Bourke-Martignoni, J. B. (2019). Engendering the right to food? International human rights law, food security and the rural woman. Transnational Legal Theor. 9, 400-414. doi: 10.1080/20414005.2018.1568789

Chan, M. K., and Mbogoh, A. (2016). Strengthening Women's Voices in the Context of Agricultural Investments: Lessons from Kenya. London; Nakuru: IIED/KLA.

\section{FUNDING}

This research was undertaken in the framework of the research project How to govern natural resources for food sovereignty? of the Centre for Agroecology, Water and Resilience (CAWR), Coventry University, funded by the 11th Hour Project.

\section{ACKNOWLEDGMENTS}

The author wishes to thank the reviewers as well as the editors for their suggestions on an earlier draft.

Charapa Consult, Rainforest Foundation, and MPIDO and Legal Assistance Center (2012). Indigenous Peoples and Climate Change in Africa: Traditional Knowledge and Adaptation Strategies. Presented to the World Bank in November 2012.

Chauveau, J. P., and Colin, J. P. (2007). "Changes in land transfer mechanisms: evidence from West Africa" in Changes in "Customary" Land Tenure Systems in Africa, ed L. Cotula (London: IIED), 65-81.

Chimhowu, A. (2019). The 'new' African customary land tenure. Characteristic, features and policy implications of a new paradigm. Land Use Policy 81, 897-903. doi: 10.1016/j.landusepol.2018.04.014

Clarke, R. A. (2009). Securing communal land rights to achieve sustainable development in Sub-Saharan Africa: critical analysis and policy implications. Law Environ. Dev. J. 5:130. Available online at: http://www.lead-journal.org/ content/09130.pdf

Collins, A. (2019). Financialization, resistance, and the question of women's land rights. Int. Feminist J. Polit. 21, 454-476. doi: 10.1080/14616742.2018.1532805

Collins, A., and Mitchell, M. I. (2018). Revisiting the World Bank's land law reform agenda in Africa: The promise and perils of customary practices. J. Agrarian Change 18, 112-131. doi: 10.1111/joac.12201

Cotula, L. (2007). Changes in "Customary" Land Tenure Systems in Africa. London: IIED.

Cotula, L., Toulmin, C., and Hesse, C. (2004). Land Tenure and Administration in Africa: Lessons of Experience and Emerging Issues. London: IIED.

Cousins, B. (2009). "Potential and Pitfalls of 'communal' land tenure reform: Experience in Africa and implications for South Africa," Paper for World Bank Conference on 'Land Governance in Support of the MDGs: Responding to New Challenges'. Available online at: https://www.fig.net/ resources/proceedings/2009/fig_wb_2009/papers/trn/trn_1_cousins.pdf

Daley, E., and Englert, B. (2010). Securing land rights for women. J. Eastern Afr. Stud. 4, 91-113. doi: 10.1080/17531050903556675

Doss, C., and Meinzen-Dick, R. (2020). Land tenure security for women: a conceptual framework. Land Use Policy 99:105080. doi: 10.1016/j.landusepol.2020.105080

Duncan, B. A., and Brants, C. (2004). Access to and Control over Land from a Gender Perspective. Rome: FAO.

Errico, S., and Claeys, P. (2020). Human rights and the commons: exploring approaches to the governance of land and natural resources beyond indigenous peoples' rights. The case of peasants. Int. J. Minority Group Rights 27, 1-33. doi: 10.1163/15718115-02604123

FAO (2011). The State of Food and Agriculture 2010-2011. Rome: FAO.

FAO (2016). Governing Tenure Rights to Commons. A Guide to Support the Implementation of the Voluntary Guidelines on the Responsible Governance of Tenure of Land, Fisheries and Forests in the Context of National Food Security. Rome: FAO.

FAO, IFAD, and WFP (2020). Rural Women and Girls 25 Years After Beijing: Critical Agents of Positive Change. Rome.

Foro Internacional de Mujeres Indígenas (2006). Indigenous Women Stand Against Violence. A Companion Report to the United Nations Secretary-General's Study on Violence Against Women. New York, NY.

Freudenberger, M. S. (2011). The Future of Customary Tenure. USAID, Property Rights and Resource Governance Briefing Paper No. 8. 
German, L., Schoneveld, G., and Mwangi, E. (2013). Contemporary processes of large-scale land acquisition in sub-Saharan Africa: legal deficiency or elite capture of the rule of law? World Dev. 49, 1-18. doi: $10.1016 /$ j.worlddev.2013.03.006

IFAD (2018). Rural Inequalities: Evaluating Approaches to Overcome Disparities. Rome: IFAD.

IIED (2006). Innovation in Securing Land Rights in Africa: Lessons from Experience. London: IIED.

IIED (2009). Land Tenure and Resource Access in West Africa: Issues and Opportunities for the Next Twenty Five Years. London: IIED.

ILC and Mokoro (2011). Gendered Impacts of Commercial Pressures on Land. Rome: ILC. Available online at: https://doc.rero.ch/record/32179/files/04Gendered_impacts_of_commercial_pressures_on_land.pdf

ILO (2021). Exploring and Tackling Barriers to Indigenous Women's Participation and Organization. A Study Based on Qualitative Research in Bangladesh, the Plurinational State of Bolivia, Cameroon and Guatemala. Geneva: ILO.

ILO/ACHPR (2009). Overview Report of the Research Project by the International Labour Organization and the African Commission on Human and Peoples' Rights on the Constitutional and Legislative Protection of the Rights of Indigenous Peoples in 24 African Countries. Geneva: ILO.

International Land Coalition (2020). Uneven Ground: Land Inequality at the Heart of Unequal Societies. Available online at: https://www.landcoalition. org/en/uneven-ground/land-inequality-solutions-resilient-sustainable- andequitable-societies/ (accessed March 14, 2021).

IWGIA (2020). The Indigenous World. Copenhagen.

KATOSI (undated). Bottom-up Accountability Initiatives to Claim Tenure Rights in Sub-Saharan Africa: Collaborative action research on the rush for land and water in Uganda, Mukono District. Available online at: https://www.tni.org/files/ publication-downloads/web_uganda_country_report.pdf (accessed March 13, 2021).

Kemigisha, P. (2021). Land tenure regimes and women's land rights in Uganda; legality and the land legal framework. Adv. Soc. Sci. Res. J. 8, 116-133. doi: 10.14738 /assrj. 81.9462

Kenfack Kenjio, J. W. (2020). Decolonizing land tenure systems in Sub-Saharan Africa: the path to modern land policy reforms. J. Land Manage. Appraisal 7, 1-9. doi: 10.5897/JLMA2020.0017

Kimani, M. (2012). Women Struggle to Secure Land Rights. Available online at: https://www.un.org/africarenewal/magazine/special-editionwomen-2012/women-struggle-secure-land-rights (accessed March 13, 2021).

Kisambu, N. (2016). Mainstreaming Gender in Tanzania's Local Land Governance. London: IIED.

Krantz, L. (2015). "Securing customary land rights in Sub-Saharan Africa," Working Papers in Human Geography 2015:1 (Department of Economy and Society, Göteborgs University). Available online at: https://core.ac.uk/ download/pdf/43558179.pdf

La Via Campesina (2015). Peasant Women Power in Mozambique Peasant Women Power in Mozambique. Via Campesina. Available online at: https:// viacampesina.org/en/peasant-women-power-in-mozambique/ (accessed August 7, 2021).

LANDESA and Resource Equity (2016). Gender and Collectively Held Land. Good Practices and Lessons Learned From Six Global Case Studies. Resource Equity and Landesa Rural Development Institute.

Lemke, S., and Claeys, P. (2020). Communication: absent voices: women and youth in communal land governance. Reflections on methods and process from exploratory research in West and East Africa. Land 9:266. doi: 10.3390/land9080266

Levien, M. (2017). Gender and land dispossession: a comparative analysis. J. Peasant Stud. 44, 1111-1134. doi: 10.1080/03066150.2017.1367291

LVC (2013). Women of Via Campesina International Manifesto. Available online at: https://viacampesina.org/en/women-of-via-campesina-internationalmanifesto-2/ (accessed March 13, 2021).

Massay, G. (2020). The struggles for land rights by rural women in subSaharan Africa: the case of Tanzania. Afr. J. Econ. Manag. Stud. 11, 271-283. doi: 10.1108/AJEMS-03-2019-0120

Matondi, P. B., Havnevik, K., and Beyene, A. (2011). Biofuels, Land Grabbing and Food Security in Africa. London; New York, NY: ZED Books. doi: $10.5040 / 9781350218673$
Mengesha, A. K., Damyanovic, D., Mansberger, R., Kassaw Agegnehu, S., and Stoeglehner, G. (2021). Reducing gender inequalities through land titling? The case of Gozamin Woreda. World Dev. 145:105532. doi: 10.1016/j.worlddev.2021.105532

NAMATI and Natural Justice (2015). Protecting community lands and resources in Africa. Available online at: https://naturaljustice.org/publication/protectingcommunity-lands-resources-africa/ (accessed March 13, 2021).

National Land Policy of Uganda (2013). Available online at: https://www.jlos. go.ug/index.php/document-centre/land-justice/366-uganda-national-landpolicy/file

Ndi, F. A. (2017). Land grabbing: a gendered understanding of perceptions and reactions from affected communities in Nguti Subdivision of South West Cameroon. Dev. Policy Rev. 37, 348-366. doi: 10.1111/dpr.12351

Nelson, J. (2004). "A survey of indigenous land tenure in sub-Saharan Africa", in Land Reform Land Settlement and Cooperatives, ed P. Groppo (Rome: FAO), 64-80.

Nolte, K., and Voget-Kleschin, L. (2014). Consultation in large-scale land acquisitions: an evaluation of three cases in Mali. World Dev. 64, 654-668. doi: $10.1016 /$ j.worlddev.2014.06.028

Nwapi, C. (2016). Land grab, property rights and gender equality in pluralistic legal orders: a Nigerian perspective. Afr. J. Legal Stud. 9, 124-146. doi: 10.1163/17087384-12340005

Osabuohien, E. S. (2014). Large scale agricultural land investments and local institutions in Africa: the Nigerian case. Land Use Policy 39, 155-165. doi: 10.1016/j.landusepol.2014.02.019

Peters, P. E. (2012). Conflicts over Land and Threats to Customary Tenure in Africa Today. CID Working Paper No. 247, Harvard University.

Peters, P. E. (2019). "Revisiting the social bedrock of kinship and descent in the anthropology of Africa," in A Companion to the Anthropology of Africa, eds R. R. Grinker, S. C. Lubkermann, C. B. Steiner, and E. Goncalves (Hoboken, NJ: John Wiley \& Sons Inc.), 33-62. doi: 10.1002/9781119251521.ch2

Platteau, J. P. (2000). "Does Africa need land reform?" in Evolving Land Rights, Policy and Tenure in Africa, eds C. Toulmin and J. Quan (London: DFID/IIED/NRI), 51-74.

Po, J. Y. T., and Hickey, G. M. (2018). Local institutions and smallholder women's access to land resources in semi-arid Kenya. Land Use Policy 76, 252-263. doi: 10.1016/j.landusepol.2018.03.055

Rose, L. (2002). African elites' land control Maneuvers. Études Rurales 163-164. Available online at: http://journals.openedition.org/etudesrurales/7979

RRI (2011). The Status of Customary Land Rights in Africa Today Rights to Resources in Crisis: Reviewing the Fate of Customary Tenure in Africa, Brief No. 4. Washington, DC: RRI. Available online at: https://rightsandresources.org/ wp-content/exported-pdf/rightstoresourcesincrisiscompiledenglish.pdf

RRI (2015). Who Owns the Land in Africa? Formal Recognition of CommunityBased Land Rights in Sub-Saharan Africa. Washington, DC: RRI

RRI (2016). Tenure foncière et Investissements en Afrique - Rapport de Synthèse. Washington, DC: RRI.

Scalise, E. (2012). "Indigenous women's land rights: case studies from Africa," in State of the World's Minorities and Indigenous Peoples 2012, ed B. Walker (London: MRG), 52-59.

Scalise, E. (2020). The gender gap, Assessing and Measuring Gender Related Land Inequality. Rome: International Land Coalition.

Tripp, A. M. (2001). Women's Movements, Customary Law, and Land Rights in Africa: The Case of Uganda. African Studies Quarterly. Available online at: http://www.africa.ufl.edu/asq/v7/v7i4a16.htm (accessed March 13, 2021).

UN Committee on the Elimination of All Forms of Discrimination against Women (2016). General Recommendation No. 34 (2016) on the Rights of Rural Women. UN Doc. CEDAW/C/GC/34.

UN Working Group on Discrimination against Women and Girls (2017). Insecure Land Rights for Women Threaten Progress on Gender Equality and Sustainable Development. Position Paper.

United Nations (2012a). Final Study of the Human Rights Council Advisory Committee on the Advancement of the Rights of Peasants and Other People Working in Rural Areas. UN Doc. A/HRC/19/75, 2012.

United Nations (2012b). Final Study of the Human Rights Council Advisory Committee on Rural Women and the Right to Food. UN Doc. A/HRC/22/72.

United Nations (2015). Report of the Special Rapporteur on the Rights of Indigenous People. UN Doc. A/HRC/30/41, 2015. 
Veit, P. (2013). Shedding Light on Land Tenure in Africa. Available online at: http://www.wri.org/blog/2013/11/shedding-light-land-tenure-africa (accessed March 13, 2021).

Williams, T. O. (1998). Multiple Uses of Common Pool Resources in Semi-Arid West Africa: A Survey of Existing Practices and Options for Sustainable Resource Management. London: Overseas Development Institute.

WoMin (African Women Unite against Destructive Resource Extraction) (undated). Women, Gender and Extractivism in Africa. Available online at: http://www.womin.org.za (accessed March 13, 2021).

Conflict of Interest: The author declares that the research was conducted in the absence of any commercial or financial relationships that could be construed as a potential conflict of interest.
Publisher's Note: All claims expressed in this article are solely those of the authors and do not necessarily represent those of their affiliated organizations, or those of the publisher, the editors and the reviewers. Any product that may be evaluated in this article, or claim that may be made by its manufacturer, is not guaranteed or endorsed by the publisher.

Copyright (c) 2021 Errico. This is an open-access article distributed under the terms of the Creative Commons Attribution License (CC BY). The use, distribution or reproduction in other forums is permitted, provided the original author $(s)$ and the copyright owner(s) are credited and that the original publication in this journal is cited, in accordance with accepted academic practice. No use, distribution or reproduction is permitted which does not comply with these terms. 